\title{
Marnie Abramson: Caring for the Bottom Line and the Planet
}

\section{Dave Feldman (Livability Project)}

\section{KEYWORDS: Construction, Entrepreneurship,} Leadership, Women, mentors.

When Marnie Abramson started her own environmental consulting business, sustainability was not yet on the radar with most companies. In fact, her partners were asked, "Why are you partnering with a green girl?" But Abramson today is a leading expert on how companies can take care of both the planet and the bottom line, and skilled at demonstrating the financial benefits from doing the right thing. Her company, NextGen Partners -- which advises companies on energy-saving lighting -- has grown into a $\$ 10$ million business and is poised for further growth.

In this interview with EIX's Dave Feldman, Abramson talks about how her experiences in her family's real estate company helped shape her current venture; why the failure of her first business led to new beginnings and increased confidence; the impact of her mentors, including her grandfather; and why she's the worst person to invite to a party.

\section{Read More:}

Advice, Best Practices and Inspiration for Women Entrepreneurs(https://eiexchange.com/women)

Additional search terms: women, female founders, women business owners, sustainability, sales, going green, environment, global warming, sustainable, climate change, environmental, sustainable business, reversing climate change, sustainable buildings, energy efficiency 